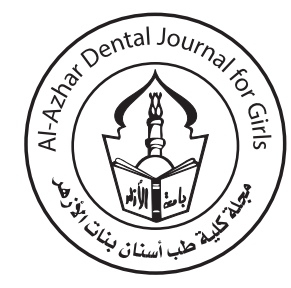

\title{
Comparative Evaluation of Natural Herbal Extracts as Root Canal Irrigation versus Routine Chemical Root Canal Irrigation
}

\author{
Kholoud M. Esmail ${ }^{*}$, Wael H. Kamel ${ }^{2}$, Mohsen Nour El-dein ${ }^{2}$, Mohamed M. El Sherif $^{3}$
}

Codex : 17/2001

azhardentj@azhar.edu.eg

http://adjg.journals.ekb.eg

DOI: $10.21608 /$ adjg.2019.9646.1126

\section{KEYWORDS}

EndoVac, $\mathrm{CHX}$,

Naocl, Neem, tea tree oil

\begin{abstract}
Purpose: This study was designed to evaluate the antimicrobial efficacy of two natural herbal extract as root canal irrigations (Neem and tea tree oil(TTO)) and two chemical root canal irrigations (sodium hypochlorite (NaOCL) and chlorhexidine $(\mathrm{CHX}))$ and compare the results with and without agitation system either with or without the use of agitation system. Materials and methods: One hundred freshly extracted intact human single rooted premolars with completely formed apex and a single root canal were selected. The specimens firstly divided into 4 experimental groups (I, II, III and IV) according to the irrigation used (20 specimens each) and 2 control groups ( $\mathrm{C} 1$ and $\mathrm{C} 2)$; positive and negative control (10 specimens each). Group (I): irrigated with $\mathrm{NaOCl}$, Group (II): irrigated with Chlorhexidine (CHX), Group (III) irrigated with Neem and Group (IV) irrigated with Tea Tree Oil (TTO). Each experimental group was subdivided into two subgroups according to the agitation system used (10 specimens each); subgroup (A): Conventional irrigation agitated with EndoVac system and subgroup (B): Conventional irrigation with no agitation. Results: The result showed that, there was a statistically significant difference in the antimicrobial efficiency produced by Neem, Tea Tree, $\mathrm{NaOCl}$ and $\mathrm{CHX}$, where $\mathrm{NaOCl}$ showed the highest antimicrobial effect, followed by Neem, CHX, while the Tea tree oil showed the lowest antimicrobial effect when conventional irrigation or EndoVac system were used $(\mathrm{P}>0.05)$. There was a statistically significant difference between irrigating techniques (conventional irrigation and EndoVac system) when Neem, Tea Tree, $\mathrm{NaOCl}$ and $\mathrm{CHX}$ used as irrigating solutions, were EndoVac agitation system has higher significance antimicrobial effect than the Conventional agitation techniques. Conclusion: Tested herbal extract is promising irrigants that used as natural substitute might prove advantageous considering the undesirable characteristics of the present used irrigant also, apical negative pressure method is more promising and effective in removing microorganisms from the root canal.
\end{abstract}

- Paper extracted from Master thesis titled "Comparative Evaluation of Natural Herbal Extracts as Root Canal Irrigation versus Routine Chemical Root Canal Irrigation "

1. Dentist at Department of Endodontics, Faculty of Dental Medicine for Girls, Al-Azhar University.

2. Professor of Endodontics, Faculty of Dental Medicine for Girls, Al-Azhar University.

3. Department of Microbiology, Faculty of Medicine, Al Azhar University.

* Corresponding author Email: kholoud.magdy@hotmail.com 


\section{INTRODUCTION}

Irrigation in endodontic is aimed to eliminate the bacteria from root canal by reducing the bacterial count which lead to control the disease in periapical $^{(1)}$

Many numbers of chemical irrigant have antimicrobial activity have been used over the years in endodontic. The continues use of chemical antimicrobial agents in endodontic lead to serious side effects. The most common side effects are microbial resistance and toxicity. Therfore, the need for alternative agents initiates to overcome this side effect. Due to this reasons interest increased in natural plant extracts as alternative effective endodontic irrigants ${ }^{(2)}$. Various natural herbs extract which have antimicrobial effect against oral common microbes \& therapeutic anti-inflammatory effects suggesting their effect to be used as an endodontic irrigant ${ }^{(3)}$.

Using herbal extracts in endodontics have many advantages besides being renewable in nature which make it more economic than chemical ones ${ }^{(4)}$.

Azadirachtaindica (neem) has powerful effect against viral, fungal, bacterial and cancer; it is used as a powerful agent for root canal irrigation. Neem extract is also used in the treatment of dental plaque and gingivitis ${ }^{(4)}$.

Tea Tree oil has a lot of properties like being an antiseptic, anti-fungal, and anti-bacterial. Tea tree oil has many advantages like it has antibacterial, anti-fungal and it has a mild solvent effect which referred to the presence of terpinen-4-ol which is responsible for the therapeutic effect so it can be used as root canal irrigant ${ }^{(5)}$

Many methods developed to make irrigation system more powerful and effective using manual and rotary mechanical agitation techniques. The manual one includes the use of needles, brushes, and dynamic agitation while the rotary techniques include rotary brushes, ultrasonic, and using EndoVAC ${ }^{(6-15)}$. Therefore, this study was designed to evaluate the antimicrobial efficacy of two natural herbal extract as root canal irrigations (neem and tea tree oil) and two chemical root canal irrigations (sodium hypochloorite and chlorhexidine) and compare the results with and without agitation system either with or without the use of agitation system.

\section{MATERIAL AND METHODS}

One hundred freshly extracted intact human single rooted premolars with completely formed apex and a single root canal were selected. The specimens firstly divided into 4 experimental groups (I, II, III and IV) according to the irrigation used (20 specimens each) and 2 control groups ( $\mathrm{C} 1$ and $\mathrm{C} 2$ ); positive and negative control (10 specimens each). Group (I): irrigated with $\mathrm{NaOCl}$, Group (II): irrigated with Chlorhexidine (CHX), Group (III) irrigated with Neem and Group (IV) irrigated with Tea Tree Oil (TTO). Each experimental group was subdivided into two subgroups according to the agitation system used (10 specimens each); subgroup(A): Conventional irrigation agitated with EndoVac system and subgroup (B): Conventional irrigation with no gitation.

- Group A1: Samples were irrigated with sodium hypochlorite $(5.25 \%$ Naocl).

- Group A2: Samples were irrigated with chlorohexidene (2\% Chx).

- Group A3: Samples were irrigated with Tea tree oil $(100 \%)$.

- Group A4: Samples were irrigated with Neem $(50 \%)$.

Each experimental groups according to use or not agitation methods (10 sample each).

- Subgroup B1: Samples were irrigated with tested irrigant and agitated with Endo Vac agitated system.

- Subgroup B2: Samples were irrigated with tested irrigant only. 
- Positive control group (C1): Samples were infected with the tested microorganisms,

- Negative control group (C2): Samples were not infected with the tested organisms

The root canals were checked with \#10 K- file until it was just visible from the root apex, in order to establish the working length, then $1 \mathrm{~mm}$ was subtracted from this length. ProTaper Universal rotary NiTi files were used in a crown down manner for root canal preparation with a 16:1 reduction hand piece that powered by torque controlled electric motor at rotational speed of $300 \mathrm{rpm}$ and torque control that adjusted according to manufacture instructions for each file used. The root canals were prepared according to the sequence presented in Table (1).

Apical foramina of all samples were sealed with light cured resin composite and samples were coated with two layers of nail varnish to prevent bacteria leakage. All roots were inserted into sterilization bags and sterilized using gamma radiation. Preparation of bacterial suspension have been done using three different types of pure cultured microorganisms which used in this test, these types are: a) $S$. aureus. b) E. faecalis. c) $C$. albicans. The microbial suspensions were prepared from microorganisms (S.aureus, E.fecealis and Candida albican)

All experimental sample and the positive controls were infused with $10 \mathrm{ml}$ of microbial mixture suspension using micropipette. For maximum penetration of the bacterial suspension into the root canal, sterile \#30 K.file was used in up and down motion. Samples placed inside eppendrofs, inserted in a rrack and incubated at $37 \mathrm{C}^{\circ}$ for 72 hours.

After incubation, each root canal was filled with sterile saline solution. A three sterile \#30 paper points were inserted into each root canal for 1 minute. Then they were transferred to sterile plastic tube containing $1 \mathrm{ml}$ physiological saline solution using sterile tweezers, then vortexes for 30 seconds, serial 10 fold dilution $(1: 10,1: 100,1: 1000)$ was done in the saline.

Bacterial infections that present in examined paper samples were investigated through culture of points on different types of agars, aiming their identification. Types of agar plates used where: Saboraud Dextrose Agar to verify the presence of

Table (1): Protoper universal rotary file sequence.

\begin{tabular}{|c|c|c|c|c|c|c|c|}
\hline $\begin{array}{l}\text { Operating } \\
\text { system }\end{array}$ & First File SX & Second File $\mathrm{S}_{1}$ & Third file $\mathrm{S}_{2}$ & Fourth file $\mathrm{F}_{1}$ & Fifth file $\mathrm{F}_{2}$ & Sixth file $\mathrm{F}_{3}$ & $\begin{array}{l}\text { Seventh } \\
\text { file } \mathrm{F}_{4}\end{array}$ \\
\hline Tip diameter & $0.19 \mathrm{~mm}$ & $0.17 \mathrm{~mm}$ & $0.20 \mathrm{~mm}$ & $0.20 \mathrm{~mm}$ & $0.25 \mathrm{~mm}$ & $0.30 \mathrm{~mm}$ & $0.40 \mathrm{~mm}$ \\
\hline Taper & $\begin{array}{l}\text { Increasing larger } \\
\text { taper over the length } \\
\text { of cutting blade }\end{array}$ & $\begin{array}{r}\text { Their } \mathrm{D}_{14} \max \\
\text { approach } \\
\mathrm{D}_{0} \\
70\end{array}$ & $\begin{array}{l}\text { nal diameter } \\
1.20 \mathrm{~mm} \\
{ }_{4}\end{array}$ & $\begin{array}{c}\mathrm{D}_{0}-\mathrm{D}_{4} \\
7 \%\end{array}$ & $\mathrm{D}_{0}-\mathrm{D}_{4} 8 \%$ & $\mathrm{D}_{0}-\mathrm{D}_{4} 9 \%$ & $\begin{array}{c}\mathrm{D}_{0}-\mathrm{D}_{4} \\
6 \%\end{array}$ \\
\hline $\begin{array}{c}\text { Preparation } \\
\text { third }\end{array}$ & Orifice opener & Coronal third & Middle third & \multicolumn{4}{|c|}{ Apical third preparation } \\
\hline Working length & \multicolumn{7}{|c|}{ At working length $(16 \mathrm{~mm})$} \\
\hline RPM & \multicolumn{7}{|c|}{$300 \mathrm{rpm}$} \\
\hline Torque & $3 \mathrm{NCM}$ & \multicolumn{2}{|c|}{$\begin{array}{c}2-3 \\
\mathrm{NCM}\end{array}$} & & $\begin{array}{l}-1.5 \\
\mathrm{CM}\end{array}$ & \multicolumn{2}{|c|}{ 2-3 NCM } \\
\hline
\end{tabular}


C.albicans, Mitis Salivaris Agar to verify E.faecalis, and blood agar to verify S.aureus.

After incubation, bacterial growth was assessed morphologically by direct smear stain by Gram stain with light microscope using oil immersion lens. All assays were conducted in duplicate under aseptic conditions to ensure the reliability of this study.

If the organisms were gram positive cocci in cluster or bunches, beta haemolytic and coagulase positive, it would be $S$. aureus. As shown in figure (1). If the organisms were gram positive cocci arranged in pairs in short chains, non-haemolytic colonies on blood agar, and can grow on Mitis Salivaris agar medium, it would be E. faecalis as shown in figure 2. If the organism were gram positive, oval shape organism showing budding with, it would be C. albicans. (figure 3).

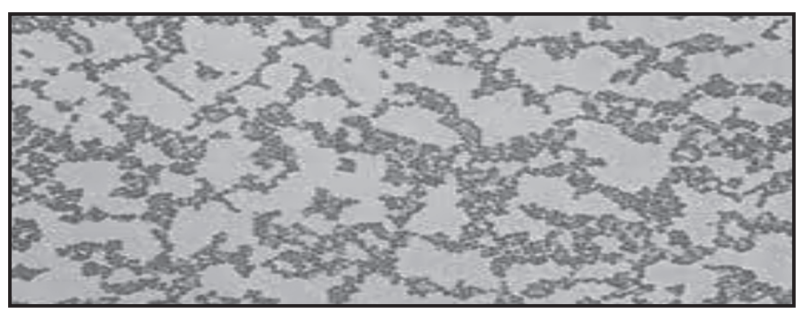

Figure (1) S. aureus stained with gram stain, and the cocci are arranged in bunches.

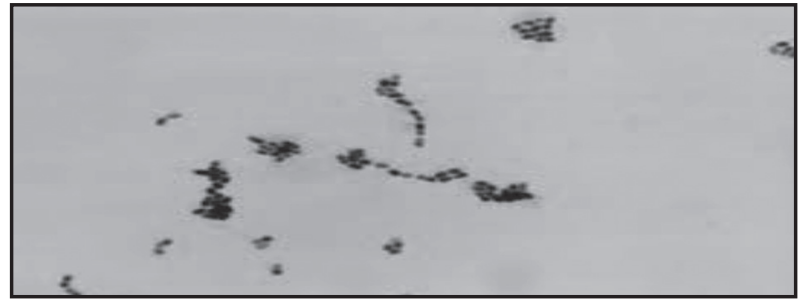

Figure (2) E. faecalis stained with gram stain and the cocci are arranged in pairs which may form short chains.

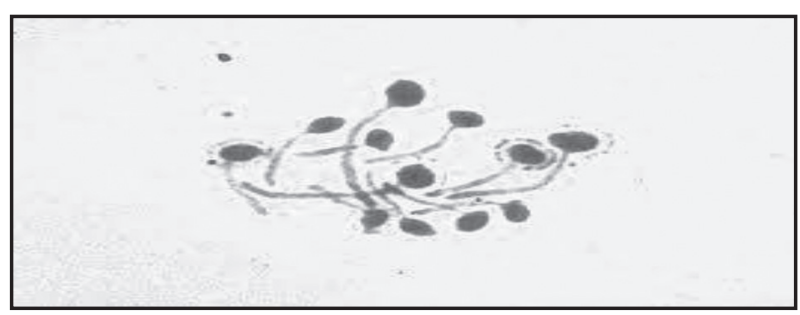

Figure (3) C. albicans stained with gram stain, some are showing pseudo-hyphae, and others are budd

Samples 'Grouping: after root canal preparation, the samples were divided into 4 experimental groups (A1, A2, A3, A4) according to irrigation used, 2 subgroups $(\mathrm{B} 1, \mathrm{~B} 2)$ according to agitation systems, and control group ( $\mathrm{C} 1$ and $\mathrm{C} 2$ ) positive and negative group respectively. As shown in figure (4)

Tea tree oil (Melaleuca alternifolia): Was purchased in the form of $100 \%$ pure commercial Australian oil, pharmaceutical grade and Neem (Azardirachtaindica) Ethanolic extract prepared and kept ready stored in airtight container

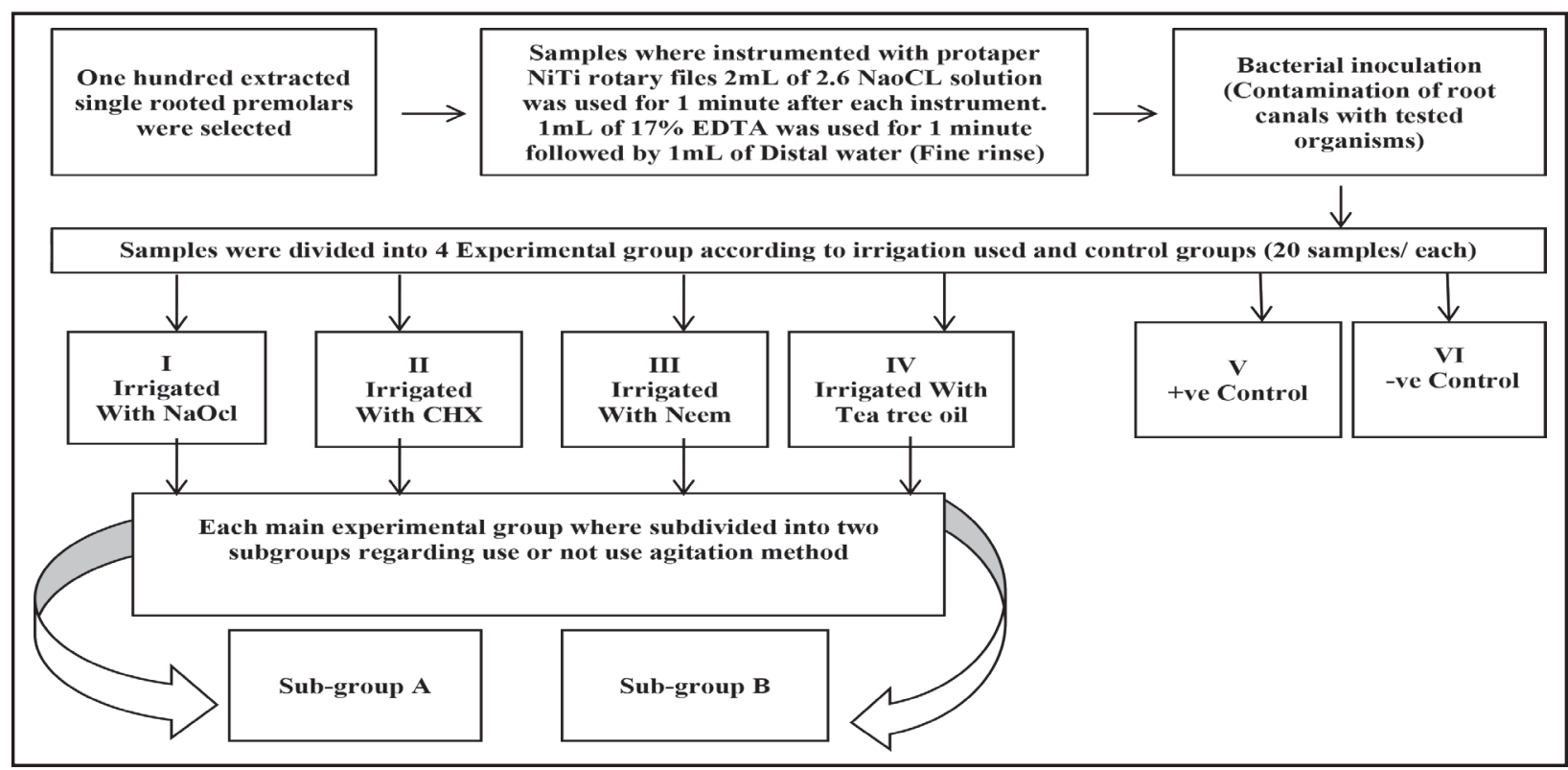

Figure (4) Grouping of the samples 
Post irrigation bacterial counting was done by visible colonies of tested organisms in every plate and then the bacterial number of colonies unit (CFUs) per milliliter was counted and calculated according to this equation: Number of colonies $(\mathrm{CFUs}) / \mathrm{ml}=($ Number of colonies $\mathrm{X}$ dilution $) /$ volume of culture plate ${ }^{(6)}$.

\section{RESULTS}

The results were presented as mean value and standard deviation. The results were compared statistically using One-way ANOVA test, T-test and post hoc test. The significance level was set to be at $\mathrm{P} \leq 0.05$. Statistical analysis has been done using IBM ${ }^{\circledR}$ SPSS ${ }^{\circ}$ Statistics Version 20 for Windows.

\section{I) Enterococcus faecalis results:}

\section{Effect of irrigation on the total bacterial count in each subgroup: (Table 2) and (Figure 5):}

\section{Subgroup(A): Conventional irrigation agitated with EndoVac system:}

Post hock test revealed that the lowest mean and standard deviation value of total bacterial count was found in $\mathrm{NaOCl}(1.38 \pm 0.09)$ followed by $\mathrm{CHX}(1.97 \pm 0.03)$, Neem $(2.03 \pm 0.6)$, TTO (2.52 \pm 0.06$)$. while the positive control show the highest mean and standard deviation value $(3.70 \pm 0.00)$. There was a significant difference between control, $\mathrm{NaOCl}$, TTO, CHXand Neemwhere $(p<0.001)$.

\section{Subgroup (b): Conventional irrigation with no agitation:}

Post hock test revealed that the lowest mean and standard deviation value of total bacterial count was found in $\mathrm{NaOCl}(1.67 \pm 0.09)$ followed by $\operatorname{Neem}(2.69 \pm 0.04),), \operatorname{CHX}(2.72 \pm 0.45)$ and TTO (2. $90 \pm 0.01)$ while the highest mean value was found in positive Control group $(3.70 \pm 0.00)$,. There was a significant difference between (Control), $(\mathrm{NaOCl})$, (TTO), (CHX) and (Neem) where $(p<0.001)$. Regarding all irrigation groups the highest mean value found in Conventional while the least mean value found in Endovac

Table (2): The mean, standard deviation (SD) values of Enterococcus faecalis of different groups.

\begin{tabular}{|c|c|c|c|c|c|}
\hline \multirow{2}{*}{ Variables } & \multicolumn{5}{|c|}{ Enterococcus faecalis } \\
\cline { 2 - 5 } & \multicolumn{2}{|c|}{ Endovac } & \multicolumn{2}{|c|}{ Conventional } & \multirow{2}{*}{ p-value } \\
\cline { 2 - 5 } & Mean & SD & Mean & SD & $1^{\text {(NS) }}$ \\
\hline Control & $3.70^{\mathrm{aA}}$ & 0.00 & $3.70^{\mathrm{aA}}$ & 0.00 & $0.016^{*}$ \\
\hline $\mathrm{NaOCl}$ & $1.38^{\mathrm{dB}}$ & 0.09 & $1.67^{\mathrm{cA}}$ & 0.09 & $<0.001^{*}$ \\
\hline $\mathrm{TTO}$ & $2.52^{\mathrm{bB}}$ & 0.06 & $2.90^{\mathrm{bA}}$ & 0.01 & \multirow{2}{*}{$\mathrm{CHX}$} \\
\hline Neem & $1.97^{\mathrm{cB}}$ & 0.03 & $2.72^{\mathrm{bA}}$ & 0.45 & $0.045^{*}$ \\
\hline p-value & $2.03^{\mathrm{cB}}$ & 0.06 & $2.69^{\mathrm{bA}}$ & 0.04 & $<0.001^{*}$ \\
\hline$<0.001^{*}$ & $<0.001^{*}$ & \\
\hline
\end{tabular}

Means with small letters indicate significance difference, means with different capital letters indicate significance difference.

*; significant at $(p<0.05)$

$N S$; non-significant at $(p>0.05)$

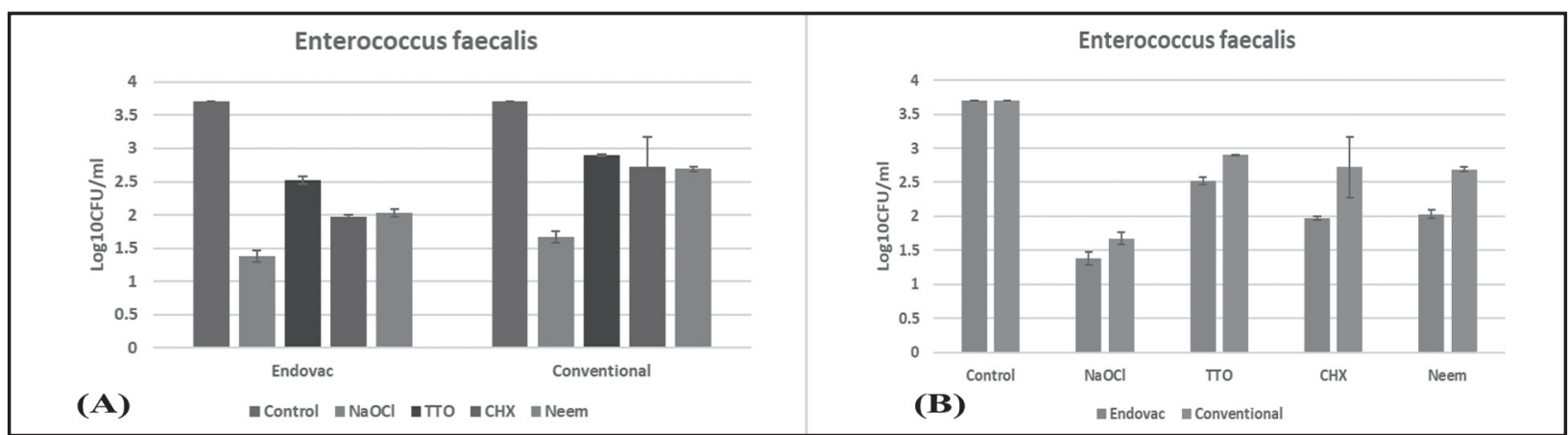

Figure (5) The mean of the total bacterial count of tested experimental groups and the positive control group within the conventional irrigation and EndoVac system and B) Bar chart representing mean of the total bacterial count of each group comparing the conventional irrigation and EndoVac system. 


\section{II) Staphylococcus results:}

\section{Effect of irrigation on the total bacterial count in each subgroup: (Table 3) and (Figure 6):}

\section{a) Conventional irrigation agitated with EndoVac system:}

Post hock test revealed that the lowest mean and standard deviation value of total bacterial count was found in $\mathrm{NaOCl}(1.51 \pm 0.03)$ followed by $\operatorname{Neem}(2.56 \pm 0.01)$, TTO $(2.59 \pm 0.02)$ and $\mathrm{CHX}(2.63 \pm 0.09)$, while the highest mean value was found in Control $(3.70 \pm 0.00)$.There was a significant difference between (Control), $(\mathrm{NaOCl})$, (TTO), (CHX) and (Neem) where $(p<0.001)$.

\section{b) Conventional irrigation with no agitation system:}

Post hock test revealed that the lowest mean and standard deviation value of total bacterial count was found in $\mathrm{NaOCl}(2.53 \pm 0.11)$, followed by Neem (2.66 \pm 0.09$), \mathrm{CHX}(3.66 \pm 0.12)$ and TTO $(3.63 \pm 0.05)$ while the highest mean value was found in Control $(3.70 \pm 0.00)$. There was a significant difference between (Control), (NaOCl), (TTO), (CHX) and $($ Neem) where $(p<0.001)$.

Table (3) The mean and standard deviation (SD) values of Staphylococcus of different groups.

\begin{tabular}{|c|c|c|c|c|c|}
\hline \multirow{2}{*}{ Variables } & \multicolumn{5}{|c|}{ Staphylococcus } \\
\cline { 2 - 5 } & \multicolumn{2}{|c|}{ Endovac } & \multicolumn{2}{|c|}{ Conventional } & \multirow{2}{*}{-value } \\
\cline { 2 - 5 } & Mean & SD & Mean & SD & -val \\
\hline Control & $3.70^{\mathrm{aA}}$ & 0.00 & $3.70^{\mathrm{aA}}$ & 0.00 & $\mathbf{1}^{\mathrm{NS}}$ \\
\hline NaOCl & $1.51^{\mathrm{cB}}$ & 0.03 & $2.53^{\mathrm{bA}}$ & 0.11 & $<\mathbf{0 . 0 0 1} *$ \\
\hline TTO & $2.59^{\mathrm{bB}}$ & 0.02 & $3.63^{\mathrm{aA}}$ & 0.05 & $<\mathbf{0 . 0 0 1} *$ \\
\hline CHX & $2.63^{\mathrm{bB}}$ & 0.09 & $3.66^{\mathrm{aA}}$ & 0.12 & $<\mathbf{0 . 0 0 1} *$ \\
\hline Neem & $2.56^{\mathrm{bB}}$ & 0.01 & $2.66^{\mathrm{bA}}$ & 0.04 & $\mathbf{0 . 0 1 5 ^ { * }}$ \\
\hline $\boldsymbol{p}$-value & \multicolumn{2}{|c|}{$<\mathbf{0 . 0 0 1}$} & \multicolumn{4}{|c|}{$<\mathbf{0 . 0 0 1 *}$} & \\
\hline
\end{tabular}

Means with small letters indicate significance difference, means with different capital letters indicate significance difference.

*; significant at $(p<0.05)$

NS; non-significant at $(p>0.05)$

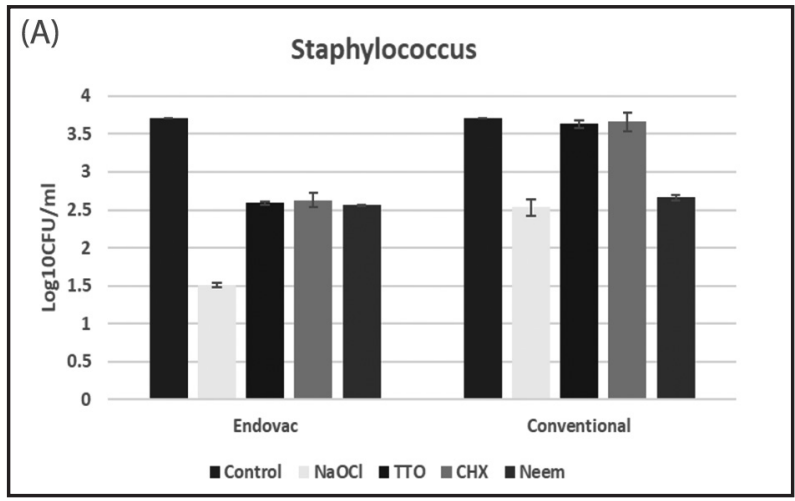

Figure (6) A) Bar chart representing mean of the total bacterial count of tested experimental groups and the positive control group within the conventional irrigation and EndoVac system

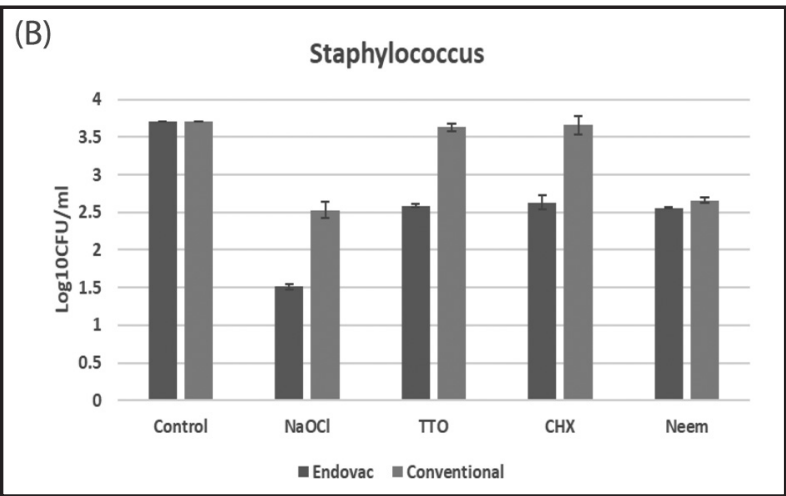

Figure (6) B) Bar chart representing mean of the total bacterial count of each group comparing the conventional irrigation and EndoVac system.

\section{III) Candida Albicans results:}

Effect of irrigation on the total bacterial count in each subgroup: (Table 4) and (Fig 7):

\section{a) Conventional irrigation agitated with EndoVac} system:

Post hock test revealed that the lowest mean and standard deviation value of total bacterial count was found in $\mathrm{NaOCl}(1.52 \pm 0.07)$ followed by $\operatorname{Neem}(2.51 \pm 0.06), \quad \operatorname{CHX}(2.52 \pm 0.01) \quad$ and $\operatorname{TTO}(2.58 \pm 0.02)$ while the highest mean value was found in Control (3.70 \pm 0.00$)$.There was a significant difference between (Control), $(\mathrm{NaOCl})$, (TTO), (CHX) and (Neem) where $(p<0.001)$. 


\section{b) Conventional irrigation with no agitation system:}

Post hock test revealed that the lowest mean and standard deviation value of total bacterial count was found in $\mathrm{NaOCl}(2.52 \pm 0.26)$ followed by Neem $(2.64 \pm 0.03), \mathrm{TTO}(3.59 \pm 0.05)$ and $\mathrm{CHX}(3.68 \pm 0.06)$ while the least mean value was found in Control(3.70 \pm 0.00$)$. There was a statistically significant difference between (Control), $(\mathrm{NaOCl})$, (TTO), (CHX) and (Neem) where $(p<0.00)$.

Table (4): The mean and standard deviation (SD) values of Candida Albicans of different groups.

\begin{tabular}{|c|c|c|c|c|c|}
\hline \multirow{3}{*}{ Variables } & \multicolumn{4}{|c|}{ Candida Albicans } & \multirow[b]{3}{*}{ p-value } \\
\hline & \multicolumn{2}{|c|}{ Endovac } & \multicolumn{2}{|c|}{ Conventional } & \\
\hline & Mean & SD & Mean & SD & \\
\hline Control & $3.70^{\mathrm{aB}}$ & 0.00 & $3.70^{\mathrm{aA}}$ & 0.00 & $1^{\mathrm{NS}}$ \\
\hline $\mathrm{NaOCl}$ & $1.52^{\mathrm{cB}}$ & 0.07 & $2.52^{\mathrm{bA}}$ & 0.26 & $0.003^{*}$ \\
\hline TTO & $2.58^{\mathrm{bB}}$ & 0.02 & $3.59^{\mathrm{aA}}$ & 0.05 & $<0.001 *$ \\
\hline CHX & $2.52^{\mathrm{bB}}$ & 0.01 & $3.68^{\mathrm{aA}}$ & 0.06 & $<0.001 *$ \\
\hline Neem & $2.51^{\mathrm{bB}}$ & 0.06 & $2.64^{\mathrm{bA}}$ & 0.03 & $0.025^{*}$ \\
\hline p-value & \multicolumn{2}{|c|}{$<0.001 *$} & \multicolumn{2}{|c|}{$<0.001 *$} & \\
\hline
\end{tabular}

Means with small letters indicate significance difference, means with different capital letters indicate significance difference.

*; significant at $(p<0.05)$

NS; non-significant at $(p>0.05)$

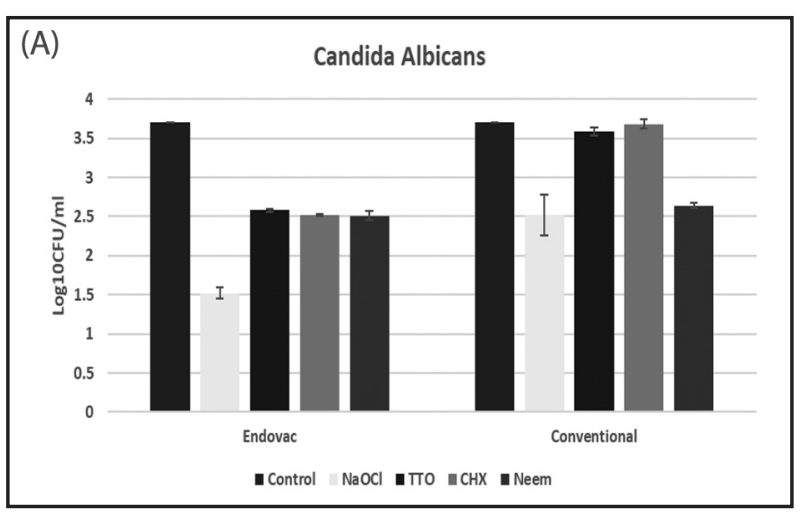

Figure (7) A) Bar chart representing Bar chart representing mean of the total bacterial count of tested experimental groups and the positive control group within the conventional irrigation and EndoVac system

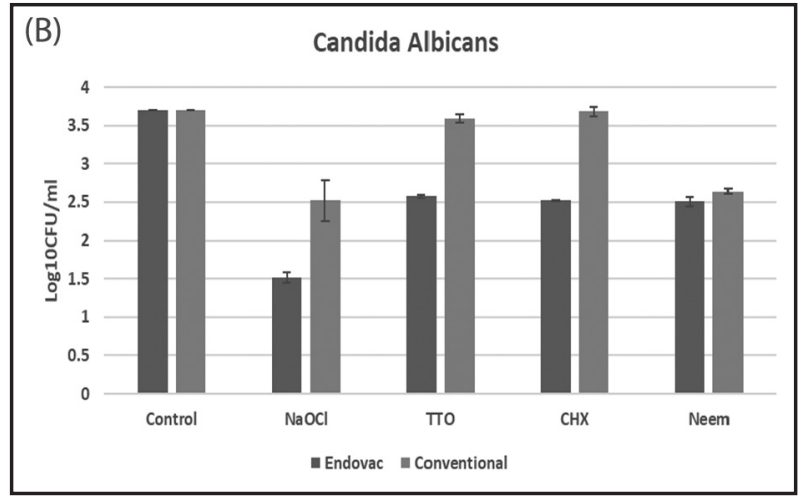

Figure (7) B) Bar chart representing mean of the total bacterial count of each group comparing the conventional irrigation and EndoVac system.

\section{DISCUSSION}

The use of irrigating solutions was an important part of endodontic treatment. The irrigants facilitate removal of necrotic tissue, microorganisms and dentin chips from the root canal by a flushing action. Irrigants help in prevent packing infected hard and soft tissue apically in the root canal and into the periapical area. As we mentioned before, the advantages of using herbal extracts in endodontics were that they have few side effects, less expensive, better tolerated by patients, high antimicrobial activity, biocompatibility, anti-inflammatory , antioxidant properties and renewable in nature ${ }^{(7)}$.

The present in vitro study was completed to compare and evaluate the effectiveness of chemicals and herbals irrigations in removing the commonly present bacteria in the root canal, and on the other hand to compare between conventional and instrumental techniques in removing bacteria present in the root canal.

The herbs investigated in the present study were Neem and Tea tree oil while the chemicals were NaOCL and CHX. The two compared techniques were Conventional irrigation technique and instrumental EndoVac ${ }^{\mathrm{TM}}$ Irrigation System. In order to stimulate clinical conditions, natural teeth where used in this study as the artificial cannot simulate natural dentine. 
Instrumentation of the apical portion of root canal to a larger file size will potentiate removal of intracanal microorganisms by reaching inaccessible areas and open the dentinal tubules to allow antimicrobials to penetrate more efficiently. Also, the microcannula of EndoVac has tip diameter of $0.32 \mathrm{~mm}$, so the minimal apical size requirement was selected per section.

Finally the teeth were sterilized; to completely eradicate all forms of bacteria that may be founded in the root canal system; by gamma rays which was effective and introduce no detectable changes in dentin while other methods (ethylene oxide, dry heat, and autoclaving) of sterilization alter the structure of the dentin, it also has the advantages of being economic method, nontoxic to both human and environment, and save the time ${ }^{(7)}$.

After that we confirm the sterilization and the culture media were inspected for growth of the bacteria to ensure absence of microorganisms inside the canal.

The microorganisms selected in the present work were; E. faecalis and C. albicans and S. aureus, they selected because of their clinical association with endodontic infection ${ }^{(8,9)}$.

Many methods used to estimate the antimicrobial effect of irrigants. Results show that the one used for the present study was proved to be proper one, as after 48 hours of incubation, all samples were infected with cultures of viable pure microorganisms ${ }^{(7,9,10)}$.

Another important step was microbial sampling that varies between the different methodologies so in the present work, samples were collected from the root canals with sterile paper points before, during, and after the biomechanical preparation with the Protaper rotary nickel titanium to estimate the antimicrobial effect of the different irrigants under the study.

Previous study showed that needle irrigation methods don't effectively disinfect the entire root canal apically, they were effective only at cleaning the root canal coronary, EndoVac was a novel irrigation system based on the negative apical pressure, where the irrigant inserted in the chamber was sucked down the root canal and back up again through a thin, specific design needle ${ }^{(11)}$. Therefore, the present study was performed to determine the effectiveness of the root canal disinfectant using the EndoVac and conventional needle in association with different irrigation solutions. In sampling step, to evaluate and compare the antimicrobial effect of the studied irrigants, as well as techniques, we perform pre-irrigation bacterial count (S1) and post irrigation bacterial count. Pre-irrigation bacterial count (S1) provides a benchmark to correctly compare the efficacy. Previously mentioned herbals and chemical irrigations were used as the irrigants in evaluating 1) Conventional manual Agitation Techniques and, 2) Apical Negative-Pressure Irrigation (Endo Vac). Each irrigation technique resulted in a highly reduction of bacteria.

Regardless the antimicrobial effect of the studied irrigants, the results of the present study showed that, the EndoVac system was significantly more effective in removing bacteria from root canals in case of herbals and chemical irrigations than conventional manual techniques. This may attributed to its advantage of being able to eliminate debris created from rotary instrumentation and necrotic pulp remnants by using a safe flow of $\mathrm{NaOCl}$ to the full working length without the risk of apical extrusion.

The post hock test results revealed that There was a significant difference between (Endovac) and (Conventional) in all the studied groups where $(p<0.001)$. Post hock test results also showed that EndoVac agitation system has higher significance antimicrobial effect than the Conventional agitation techniques.

This was agreement with other studies that shown that the using the EndoVac system have many advantages in enhancing cleaning ability of the root canal in compare to other irrigations systems ${ }^{(11-15)}$. 
These findings confirmed the importance of mechanical instrumentation combined with the use of antibacterial irrigation in disinfecting root canals.

Previous studies have reported that the EndoVac ${ }^{\mathrm{TM}}$ System was safe and effective in irrigation of the root canal especially in the apical third ${ }^{(11-17)}$.

There were currently few studies that examine how well these devices remove bacteria from the root canal in irrigation. Two previous studies confirmed that the use of EndoVac in irrigation to remove bacteria from the root canal was more effective than needle irrigation group ${ }^{(11)(17)}$.

Regardless of the technique we used for irrigation, the results of the present study revealed that; there was no significant difference between $(\mathrm{CHX})$ and $(\mathrm{Neem})$ statistically where $(\mathrm{p}=0.720)$ so it's better to use Neem in combine with $\mathrm{CHX}$ or instead of it to avoid its harmful effect.

Although there was no difference statistically between the antimicrobial effect of both CHX and Neem, the antimicrobial effect of CHX was much higher, this was may be attributed to the mechanism of antimicrobial action of CHX, as it has antimicrobial efficacy against wide range of microorganisms based on its mechanism of action as it work by interaction done between the positive charge molecules present in CHX and negative charge one on the cell wall of bacteria (phosphate groups), which allows deep penetration of CHX molecule inside the bacteria.

This was confirmed by other studies, which stated that Azadirachta Indica extract as irrigation exhibited significant resistance to E. Faecalis colonization $^{(4,19,17)}$.

Another studies compared the efficacy of neem extract and $\mathrm{NaOCL}$ as antimicrobial agent against E.Faecalis and C. Albicans and it was concluded that neem extract had significant antimicrobial activity against these organisms ${ }^{(20,21,22)}$.
On other hand the results found that tea tree oil showed significant difference with control group which confirmed the significant antimicrobial effect on S. aureus, E.faecalis and C. albicans which was confirmed by previous study ${ }^{(23,24,25)}$.

Regardless of agitation system, results revealed also that $\mathrm{NaOCl}$ has the highest significance antimicrobial effect, followed by chlorhexidine, Neem and Tea tree oil. Results also confirmed that no significant difference was found between (TTO) and each of $(\mathrm{CHX})$ and $(\mathrm{Neem})$ where $(\mathrm{p}=0.820)$ and $(\mathrm{p}=0.708)$ respectively. Also $\mathrm{NaOCl}$ has the highest significance antimicrobial effect, followed by Neem, chlorhexidine, and Tea tree oil which may attributing to NaOCL good tissue dissolution properties and excellent antimicrobial activity ${ }^{(26,27)}$.

\section{CONCLUSION}

Using apical negative pressure method (EndoVac) is more effective in removing microorganisms from the root canal as it increase the antimicrobial in case of herbals and chemical irrigations than conventional manual techniques. $\mathrm{NaOCl}$ has the highest significance antimicrobial effect, followed by CHX, Neem and TTO.

\section{REFERENCES}

1. Takashi K. Clinical Cases in Endodontics. John Wiley \& Sons. First Edition, 2018.

2. Siqueira JF, Rôças I. Clinical implications and microbiology of bacterial persistence after treatment procedures. J Endod. 2008, 34;1291-1301.

3. Luis D P, Chávez E. Aetiology of persistent endodontic infections in root-filled teeth. In: Apical Periodontitis in Root-Filled Teeth. Springer Cham. 2018, 21-32.

4. Arun P, Pare P. A review: Antimicrobial activity of Azadirachta indica (Neem). Int J of Pharm Life Sci. 2018, 9.3; 5755-6.

5. Sinha D J, Vasudeva A, Gowhar O, Garg P, Sinha A, Prakash P. Comparison of antimicrobial efficacy of propolis, Azadirachta indica (Neem), Melaleuca alternifolia (Tea tree oil), Curcuma longa (Turmeric) and 5\% sodium hypochlorite on Candida albicans biofilm formed on tooth 
substrate: An in-vitro study. J Pharm Biomed Sci. 2015, $5 ; 469-74$.

6. Morel A, Peeters N, Vailleau F, Barberis P, Jiang G, Berthomé R, et al. Plant Pathogenicity Phenotyping of Ralstonia solanacearum Strains. In Host-Pathogen Int Human. Press New York NY. 4;2018, 223-9.

7. Türker N S, Özer A Y, Kutlu B, Nohutcu R, Sungur A, Bilgili H, Özalp, M. The effect of gamma radiation sterilization on dental biomaterials. Tissue Engineering and Regenerative Medicine. 2014,11;341-9.

8. Zoletti G, Siqueira J, Santos K. Identification of Enterococcus faecalis in Root-filled Teeth With or Without Periradicular Lesions by Culture-dependent and Independent Approaches. J Endod. 2006, 32;722-6.

9. Darcey J, Jawad S, Taylor C, Roudsari R V, Hunter M. Modern endodontic principles part 4: irrigation. Dental update. 2016,$43 ; 20-33$.

10. Plotino G, Cortese T, Grande N M, Leonardi D P, Di Giorgio G, Testarelli L, et al. New technologies to improve root canal disinfection. Braz Dent J. 2016, 27; 3-8.

11. Park E. Ultrasonics in endodontics. Endodontic Topics. 2013, 29; 125-59.

12. Mancini M, Cerroni L, Iorio L, Dall'Asta L, Cianconi L. FESEM evaluation of smear layer removal using different irrigant activation methods (EndoActivator, EndoVac, PUI and LAI). An in vitro study. Clin oral investig. 2018, 22;993-9.

13. Venumbaka N R, Baskaran P, Mungara J, Chenchugopal M, Elangovan A, Vijayakumar. PComparative Evaluation of Endovac and Conventional Irrigating Syringe on Apical Extrusion in Primary Molars. An in vitro Study. JOCPD. 2018, 355-60.

14. Chris S, Baumgartner J. Comparison of the debridement efficacy of the EndoVac irrigation system and conventional needle root canal irrigation in vivo. J Endod. 2010, 36.11; 1782-5.

15. Daga P. Comparative Evaluation of Antimicrobial Efficacy of Neem, Miswak, Propolis, and Sodium Hypochlorite against Enterococcus faecalis using EndoVac. IJOPRD. 2017, 7;60-5.

16. Olivi G, DiVito E E. Advanced Laser-Activated Irrigation: PIPS TM Technique and Clinical Protocols In Lasers in Endodontics.Springer. 2016, 219-91.

17. Dubey S, Chaodary M, Gupta P. Comparative study of the antimicrobial efficiency of Neem leaf extract , Sodium hypochlorite and Biopure MTAD - An in vitro study. IJDA. 2012, 4;740-3.

18. Hedge V. Enterococcus faecalis; clinical significance and treatment considerations. Endodontology. 2009, 21;48-52.

19. VinothkumarT S, Rubin M I, Balaji L, Kandaswamy D. In vitro evaluation of five different herbal extracts as an antimicrobial endodontic irrigant using real time quantitative polymerase chain reaction. J Conserv Dent. 2013, 16; 167-70.

20. Mustafa M. Antibacterial Efficacy of Neem (Azadirachta indica) Extract against Enterococcus faecalis: An in vitro Study. JCDP. 2016, 17; 791-4.

21. Kamath U, Sheth H, Ramesh S, Singla K .Comparison of the Antibacterial Efficacy of Tea Tree Oil with 3\% Sodium Hypochlorite and 2\% Chlorhexidine against E. faecalis: An in vitro Journal of Contemporary Dentistry. 2013,3; 117-20.

22. Thosar N, Basak S, Bahadure R N, Rajurkar M. Antimicrobial efficacy of five essential oils against oral pathogens: An in vitro study. Eur J Dent. 2013, 7;71-7.

23. Sinha, D J, Vasudeva, A, Jaiswal N, Garg P, Tyagi S P,Singh J. Antibacterial efficacy of Melaleuca alternifolia (Tea tree oil), Curcuma longa (Turmeric), $2 \%$ chlorhexidine, and 5\% sodium hypochlorite against Enterococcus faecalis: An in vitro study. Saudi Endodo J. 2015, 5; 182-6

24. Alagl A, Bedi S, Almas K, Phytosolutions for Enterococcus faecalis in Endodontics: An Update. OHDM. 2017.

25. Yamashita J, Tanomaru Filho M, Leonardo M, Rossi M, Silva L. Scanning electron microscopic study of the cleaning ability of chlorhexidine as a root canal irrigant. IEJ. 2003, 36; 391-4. 